\section{Association Between In-Office And At-Home Tooth Bleaching: A Single Blind Randomized Clinical Trial}

João Lima Rodrigues¹, Patrícia Souza Rocha², Silvia Letícia de Souza Pardim² $^{2}$ Ana Cláudia Vieira Machado ${ }^{1}$, André Luis Faria-e-Silva ${ }^{3}$, Paulo Isaías Seraidarian ${ }^{4}$

This controlled randomized clinical trial evaluated the effect of associating at-home and in-office bleaching procedures on tooth sensitivity (TS) and bleaching effectiveness. Forty patients subjected to on session of in-office bleaching with 38\% peroxide hydrogen. Subsequently, the patients were randomly allocated to receive a second session of inoffice bleaching or to use a tray containing 10\% carbamide peroxide delivered during 7 consecutive days. The worst TS score reported during or after each bleaching procedure was recorded using a verbal rating scale and TS risk (score different from 0 ) was calculated. Color changes were measured 7 days after each in-office session (for patients receiving in-office procedures only) or after the end of at-home bleaching (for the combined protocol), and 6 months after the last procedure for both bleaching protocols. Color was assessed by a spectrophotometer and by color match with the Vita Classical and Bleach guide scales. Statistical analyses were carried out to assess possible differences between the protocols regarding the outcomes and to analyze the effect of time of assessment on color changes. The bleaching protocol did not affect the risk for and the maximum level of TS reported, irrespective of the time of assessment. In the color evaluation, the bleaching protocol also did not affect the ultimate tooth color. In conclusion, after one in-office bleaching session, there was no difference in bleaching effectiveness and TS between performing a second in-office session and associating it with 1-week at-home bleaching.
'PUC Minas - Pontifícia Universidade Católica de Minas Gerais, Belo Horizonte, MG, Brazil ${ }^{2}$ FUNORTE - Faculdades Unidas do Norte de Minas, Montes Claros, MG, Brazil ${ }^{3}$ Department of Dentistry, UFS - Universidade Federal de Sergipe, Aracaju, SE, Brazil ${ }^{4}$ Department of Prosthodontics, PUC Minas - Pontifícia Universidade Católica de Minas Gerais, Belo Horizonte, MG, Brazil

Correspondence: André Luis Faria e Silva, Rua Cláudio Batista, s/n, Sanatório, 49060-100 Aracaju, SE, Brasil. Tel: +55-79-2105-1821. e-mail: fariaesilva.andre@gmail.com

Key Words: tooth bleaching, tooth sensitivity, hydrogen peroxide.

\section{Introduction}

Bleaching is a usual conservative clinical procedure carried out by clinicians to solve esthetic problems associated with tooth discoloration. This esthetic procedure can be performed either by clinicians in the office using high concentrations of hydrogen peroxide or by patients at home using customized trays that deliver peroxide (usually carbamide peroxide) at low concentrations $(1,2)$. Irrespective of the technique chosen, satisfactory bleaching effectiveness has been reported for most cases of tooth discoloration when the procedure is well conducted $(2,3)$. However, tooth sensitivity (TS) reported by patients is a common adverse effect associated with bleaching procedures, mainly when a high concentration of peroxides is used in the office (2-5).

Regardless of the higher incidence of TS than that observed for at-home techniques, in-office bleaching remains a useful technique to treat tooth discoloration when patients have any contraindication, such as gingival retraction or gastric disease, for the use of peroxidedelivering trays $(6,7)$. Moreover, the fact that clinicians do not have to rely on patient collaboration and have increased control over the procedure provides additional advantages to in-office bleaching. Another important aspect is the time of treatment required to obtain the tooth color desired by the patient.

Since more than one in-office bleaching session is usually necessary to achieve satisfactory results, the time required between consecutive sessions (usually 1 week) for reduction of pulp inflammation caused by high concentrations of peroxides delays treatment (8-10). Therefore, in order to accelerate the bleaching process, the association of in-office and at-home procedures has been suggested (11-14). In the combined technique, a customized tray and a bleaching agent with a low concentration of peroxide are given to the patient after the first in-office session to be used at home. However, the possible advantages of the combined technique in accelerating tooth bleaching or its effect on tooth sensitivity are not fully elucidated. Kugel et al. (11) compared the combined technique to two 15-min application of 35\% carbamide peroxide, and the low concentration of bleaching (corresponding to approximately $12 \%$ hydrogen peroxide) (15) agent used for a short time could justify the improved outcomes observed for combined technique. Another prior study (13) evaluated the additional effect of at-home bleaching following in-office protocol with 36\% hydrogen peroxide (used for three 15-minute or a single 40-min applications). 
As expected, combined technique resulted in improved bleaching effect since no additional bleaching procedure was performed when only in-office technique was used.

Thus, the aim of this clinical trial was to assess bleaching effectiveness and TS level reported by patients subjected to a single in-office bleaching session combined with at-home bleaching for 7 consecutive days compared to two in-office bleaching sessions with a 1-week interval between them. The null hypothesis of the study was that the combined technique did not alter: 1) the incidence and level of TS and 2) the ultimate tooth color when compared to the two in-office bleaching sessions.

\section{Material and Methods}

This clinical trial was approved by the committee for the protection of human subjects of the local university (process no. CAAE 47633615.6.0000.5141). This study was a single blind randomized clinical trial with a parallel design conducted from February 2016 to September 2016. Prior to the bleaching procedures, all volunteers underwent dental screening and rubber cup prophylaxis with pumice and water.

\section{Sample Size Calculation}

The sample size calculation used the absolute risk of TS as primary outcome and data from a previous study with two in-office bleaching sessions with 1-week interval between them and a reported TS risk of 90\% (16). The calculation was performed for equivalence trial with a binary outcome, considering a test power of $80 \%$, a significance level of $5 \%$ and an equivalence limit of 30\%. Thus, 40 patients (20 per experimental condition) were included in the study based on the sample size calculation.

\section{Random Sequence Generation and Allocation Concealment}

A randomized list was computer-generated by a person not involved in the intervention or evaluation. The sequence of allocation was inserted into opaque sealed envelopes numbered from 1 to 40 that were opened by the operator only at the time of the intervention. The patients were numbered according to the sequence of enrollment.

\section{Inclusion and Exclusion Criteria}

Patients included in this clinical trial were at least 18 years old, had good general and oral health and all six maxillary anterior teeth with shade A2 or darker, according to the Vita Classical (Vita-Zahnfabrik, Bad Säckingen, Germany) shade guide. The participants were required to have caries-free maxillary anterior teeth without restorations and/or endodontic treatment. Participants who had undergone tooth-whitening procedures, were pregnant or lactating, had severe internal tooth discoloration (e.g. tetracycline stains), were taking any kind of medicine, had bruxism or any other pathology that could cause TS (such as gingival recession or dentin exposure), were smokers or had periodontal disease were excluded from the study.

\section{Baseline Measurements}

Prior to the bleaching procedures, both TS and shade of the six maxillary anterior teeth were evaluated. TS was evaluated using a 5-point verbal rating scale (VRS), where $0=$ none, 1 mild, $2=$ moderate, $3=$ considerable and $4=$ severe. Patients whose scores were different from 0 when a gentle air stream was applied over the buccal surfaces of maxillary teeth were excluded. A spectrophotometer (Easy Shade Compact, Vita-Zahnfabrik) was used to assess tooth color. A silicone index extending from canine to canine containing a 6-mm hole for the placement of the spectrophotometer tip was used to standardize the readings. Three assessments were performed on each tooth, and the average was recorded. Color was also evaluated by Vita Classical and Bleach (Vita-Zahnfabrik) guide scales and by comparing the shade tabs with the middle third of the teeth.

\section{Intervention}

All patients included in the study were subjected to one in-office bleaching session in their first appointment. The gingival tissue of the teeth to be bleached was isolated using a light-cured resin dam and 38\% hydrogen peroxide gel (Opalescence Boost, Ultradent, Indaiatuba, SP, Brazil) was applied over the buccal tooth surfaces. Peroxide was maintained undisturbed for $45 \mathrm{~min}$ in a single application, according to prior clinical trial (17) that did not find difference between the protocol used in the present study and three consecutive 15-minutes applications (manufacturer's recommendation). Thereafter, based on the randomized list, the patients allocated to the combined technique received a customized tray and a bleaching agent (10\% carbamide peroxide, Opalescence PF 10\%) (Ultradent) to be inserted into the tray before at-home bleaching. These participants were instructed to perform the at-home bleaching procedure using the filled tray for at least $4 \mathrm{~h}$ every day during 7 consecutive days. The other participants, allocated to the in-office technique only, returned after 1 week for a second in-office tooth bleaching session following the same protocol described previously.

\section{Evaluations}

The worst TS score reported by patients during or after each bleaching protocol was recorded. The absolute risk of TS was calculated based on the percentage of scores different from 0 observed during or after each in- 
office session and during the entire at-home bleaching. Color evaluation of the six maxillary anterior teeth was repeated 1 week after each in-office bleaching session for those participants subjected exclusively to this type of procedure. For the participants allocated to the combined technique, color evaluation was performed 1 week after the last day using the tray containing the bleaching agent. All participants in both bleaching protocols returned after 6 months for evaluation of color stability. In each assessment, $\Delta \mathrm{E}$ was calculated based on the following equation: $\Delta \mathrm{E}=\left[(\Delta \mathrm{L})^{2}+(\Delta \mathrm{a})^{2}+(\Delta \mathrm{b})^{2}\right]^{1 / 2}$. Shade guide units (SGU) were calculated by subtracting the scores in each assessment from those measured at baseline. All evaluations were performed by an evaluator who were blinded to the allocation assignment.

\section{Statistical Analysis}

Age and gender of participants allocated to each bleaching protocol were compared by the t-test and Fisher's exact test, respectively. The scores recorded for tooth color for participants in each protocol were compared to baseline ones by the Mann-Whitney test.

In each assessment, the color changes between the protocols were compared by the Mann-Whitney test (for SGUs on both scales) or by the t-test (for $\Delta \mathrm{E}$ ). Measurements of in-office bleaching 1 week after the first and second sessions were compared to those performed 1 week after the ending of at-home bleaching. The effect of time of assessment on color changes was analyzed by the Friedman or Wilcoxon test (for SGUs on both scales) and by one-way repeated measures ANOVA or the paired t-test (for $\Delta \mathrm{E}$ ).

In each assessment, the absolute risk of TS between the protocols was compared using Fisher's exact test. Relative risks with their confidence intervals were also calculated using the protocol with two in-office sessions as control. The comparison between the protocols regarding the maximum levels of TS after each bleaching procedure was performed by the Mann-Whitney test. The data were analyzed by the SigmaStat v.3.5 statistical software package (Systat Software Inc., Chicago, IL, USA). The significance level was set at $\alpha=0.05$ for all analyses.

\section{Results}

Table 1 presents the characteristics of the samples at baseline. No differences in age and gender were found between participants in each protocol. Most participants were female (60\% for both protocols) and young (around 24 years old). Color scores were similar between the teeth allocated to the two in-office sessions and to those subjected to the combined protocol. Figure 1 presents the flowchart with the participants included in the study.

The color evaluation results are presented in Table 2. Irrespective of the tool used to measure color changes, no differences between the evaluated protocols were observed at any time of assessment. The second in-office session had an additional bleaching effect, but with no difference in the color obtained by at-home bleaching (combined protocol). No significant rebound color effect was observed after 6 months. Both protocols presented similar risk of TS during or after the bleaching procedures (Table 3). The maximum level of TS was also similar for both protocols (Fig. 2).

\section{Discussion}

In addition to seeking improvements in smile esthetics, patients frequently undergo faster and painless procedures to treat tooth discoloration. Despite satisfactory esthetic results, in-office tooth bleaching has a high incidence of TS and usually requires two or three around 1-hour sessions for a satisfactory bleaching effect $(2,3)$. As TS is related to pulp inflammation, the delay of around 1-week between two sessions has been considered to reduce this inflammatory process without additional damage to the pulp tissue (10). On the other hand, the use of a bleaching tray for 1 week immediately after the in-office bleaching does not allow reducing pulp inflammation and could increase the risk and level of TS when compared to two in-office bleaching sessions with a 1-week interval between them. However, both protocols evaluated in the present study presented similar risk and maximum level of TS, leading us to accept the first null hypothesis.

The sensitivity reported by patients following tooth bleaching procedures is related to inflammatory processes induced by the presence of peroxide and its products in

Table 1. Characteristics of the samples at baseline

\begin{tabular}{|c|c|c|c|}
\hline Characteristics & In-office & Combined & p-value \\
\hline Age [Mean in years (SD)] & $24.5(5.3)$ & $23.7(4.7)$ & $0.619^{1}$ \\
\hline Gender [Male/Female] & $6 / 14$ & $6 / 14$ & $1.000^{2}$ \\
\hline Color on Vita Classic - Median (1st/ 3rd quartiles); scores & $8.8(7.6 / 10.1)$ & $8.5(7.1 / 9.2)$ & $0.481^{3}$ \\
\hline Color on Vita Bleach guide- Median (1st/ 3rd quartiles); scores & $8.3(8.2 / 8.5)$ & $8.5(7.7 / 8.8)$ & $0.978^{3}$ \\
\hline
\end{tabular}

SD: Standard deviation. 1. t-test; 2. Fisher's exact test; 3. Mann-Whitney test. 
the pulp chamber, reducing the possibility of pulpal cell proliferation, its metabolism and viability, and compromising the reparative capacity of pulp (18-22). Moreover, oxidative stress caused by peroxide penetration into the pulp chamber increases the level of inflammation mediators such as prostaglandins, bradykinin and substance $P$, while the presence of bradykinin is responsible for tooth pain $(23,24)$. Studies evaluating the time required to reverse the inflammatory process are usually conducted using cultured pulp cells or teeth extracted from humans or dogs $(19,22,25-$ 27). It has been demonstrated that bleaching-induced inflammatory reaction is a slow but reversible process, as only after 60 days it is possible to observe absence of hemorrhage, of resorption, or of inflammatory infiltration (25). Thus, for both bleaching protocols evaluated, there was some degree of pulp inflammation during the second application of the bleaching agent (at-home or in-office) following the first in-office bleaching session. However, considering that a reduction in the inflammatory process is time-dependent, a lower degree of inflammation could be expected 1 week after the first bleaching session rather than 1 day after that. Thus, the presence of a more inflamed pulp in the combined protocols could favor TS development even at lower concentrations of the bleaching agent containing 10\% carbamide peroxide (corresponding to $3.3 \%$ hydrogen peroxide) $(15,28,29)$.

Regarding bleaching effectiveness, factors other than the bleaching technique have been related to color changes, including tooth color at baseline and patient age. A stronger bleaching effect tends to occur in darker teeth and younger

Table 2. Results of color evaluation performed with scales and spectrophotometer

\begin{tabular}{|c|c|c|c|c|}
\hline Color measurement & Time of assessment ${ }^{*}$ & In-office & Combined & $\mathrm{p}$-value \\
\hline \multirow{4}{*}{$\begin{array}{l}\text { Vita Classic } \\
\text { Median (1st/ 3rd quartiles); } \Delta \mathrm{SGU}\end{array}$} & 7 days & $-4.2(-5.4 /-3.3)^{\mathrm{A}}$ & $-5.0(-6.4 /-4.4)$ & $0.053^{1}$ \\
\hline & 14 days & $-5.6(-6.5 /-4.8)^{\mathrm{B}}$ & - & $0.350^{1 *}$ \\
\hline & 6 months & $-5.6(-6.5 /-4.8)^{\text {В }}$ & $-5.7(-6.7 /-3.9)$ & $0.561^{1}$ \\
\hline & $\mathrm{p}$-value & $<0.001^{2}$ & $0.970^{3}$ & \\
\hline \multirow{4}{*}{$\begin{array}{l}\text { Vita Bleach guide } \\
\text { Median (1st/ 3rd quartiles); } \Delta S G U\end{array}$} & 7 days & $-2.3(-2.7 /-2.3)^{\mathrm{A}}$ & $-2.8(-3.9 /-2.3)$ & $0.072^{1}$ \\
\hline & 14 days & $-3.3(-3.3 /-2.8)^{\mathrm{B}}$ & - & $0.192^{1 *}$ \\
\hline & 6 months & $-3.2(-3.5 /-2.8)^{\text {В }}$ & $-3.0(-4.0 /-2.5)$ & $0.714^{1}$ \\
\hline & $\mathrm{p}$-value & $<0.001^{2}$ & $0.156^{3}$ & \\
\hline \multirow{4}{*}{$\begin{array}{l}\text { Spectrophotometer } \\
\text { Means (SD); } \Delta \mathrm{E}\end{array}$} & 7 days & $6.9(1.6)^{\mathrm{B}}$ & $7.8(2.7)$ & $0.122^{4}$ \\
\hline & 14 days & $9.7(3.0)^{\mathrm{A}}$ & - & $0.189^{4^{*}}$ \\
\hline & 6 months & $9.5(2.0)^{\mathrm{A}}$ & $8.4(3.1)$ & 0.580 \\
\hline & $p$-value & $<0.001^{5}$ & $0.112^{6}$ & \\
\hline
\end{tabular}

$¥$ - After the 1st bleaching procedure. 1. Mann-Whitney; 2. Friedman; 3. Wilcoxon; 4. t-test; 5. One-way repeated measures ANOVA; 6. Paired t-test. Different letters indicate statistical differences $(\mathrm{p}<0.05)$. ${ }^{*}$ The evaluation after 14 days for the in-office technique was compared with the values observed 7 days after the end of the combined technique.

Table 3. Risk for tooth sensitivity caused by tooth bleaching throughout treatment

\begin{tabular}{|c|c|c|c|c|c|}
\hline Time of assessment & Bleaching protocol & $\begin{array}{l}\text { Presence/absence of } \\
\text { tooth sensitivity }\end{array}$ & $\begin{array}{c}\text { Absolute risk } \\
(95 \% \mathrm{CI})\end{array}$ & $\begin{array}{l}\text { Relative Risk } \\
(95 \% \mathrm{CI})^{*}\end{array}$ & p-value ${ }^{1}$ \\
\hline \multirow{2}{*}{ 1st bleaching } & In-office & $17 / 3$ & $0.85(0.64-0.95)$ & \multirow{2}{*}{$1.00(0.77-1.30)$} & \multirow{2}{*}{1.000} \\
\hline & In-office (combined) & $17 / 3$ & $0.85(0.64-0.95)$ & & \\
\hline \multirow[b]{2}{*}{ 2nd bleaching } & In-office & $16 / 4$ & $0.80(0.58-0.92)$ & \multirow[b]{2}{*}{$0.63(0.38-1.02)$} & \multirow[b]{2}{*}{0.096} \\
\hline & $\begin{array}{l}\text { At-home } \\
\text { (combined) }\end{array}$ & $10 / 10$ & $0.50(0.30-0.70)$ & & \\
\hline
\end{tabular}

1. Fisher's exact test. * Considering in-office as control. CI - Confidence interval. 
patients (3). In the present study, no difference in age and color was observed at baseline between the patients allocated to the combined technique or exclusively to in- office bleaching procedures, while a moderate degree of darkness was seen in young participants included in both bleaching protocols. An important observation is that the

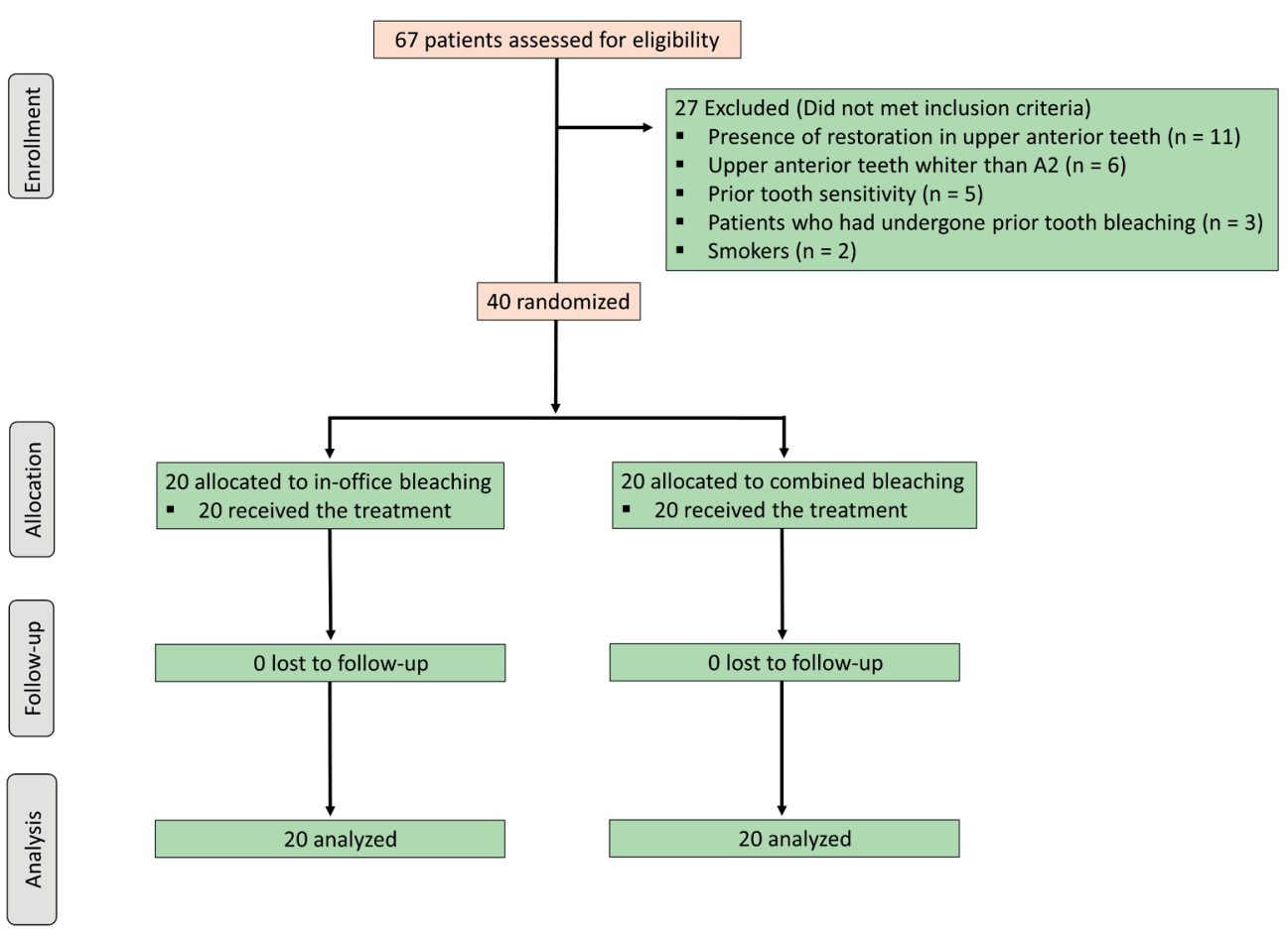

Figure 1. Flowchart of participants included in the study.

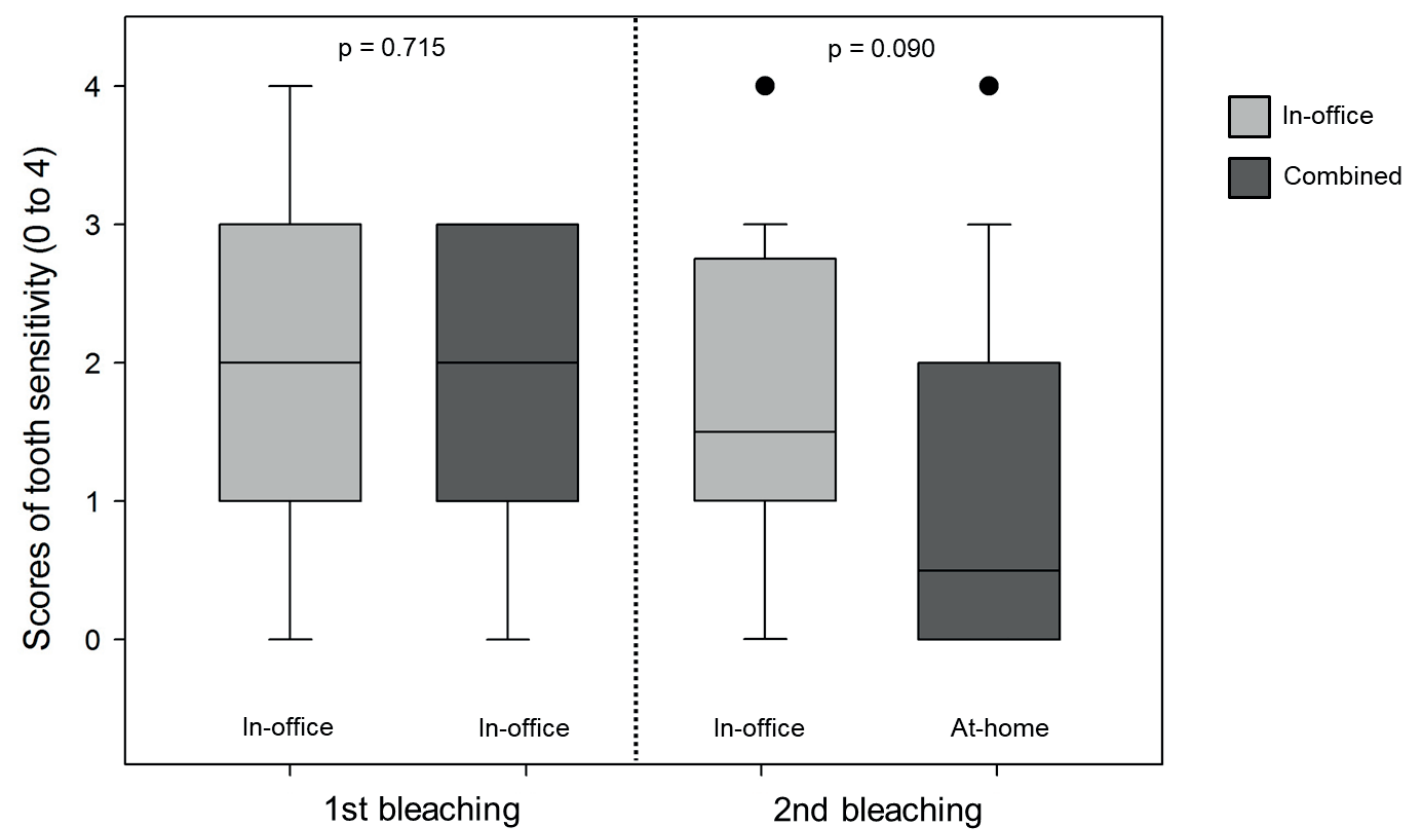

Figure 2. Box-plot presenting the maximum level of tooth sensitivity reported by participants after each bleaching procedure. p-value calculated by the Mann-Whitney test. 
color change obtained after the in-office session in the combined protocol was not measured. Teeth tend to appear whiter immediately after the in-office bleaching procedure due to dehydration from the isolation and demineralization caused by acidity of the bleaching agent, and a few days are required to reverse this process $(30,31)$. Since at-home bleaching began one day after in-office bleaching, the delay was not enough to effectively measure the bleaching effect achieved with the first bleaching procedure. However, it is possible to state that a similar color change was obtained for both protocols following the in-office bleaching carried out in the first appointment. Thus, the absence of significant difference between the color changes measured 1 week after the end of the combined protocol and 1 week after the first in-office session demonstrated that at-home bleaching had limited effect on tooth color. Nevertheless, it is important to emphasize that the color measured 1 week after the end of the combined protocol was similar to that achieved with two in-office bleaching sessions at the same time of assessment, despite the fact that the second in-office bleaching session improved the bleaching effect. Actually, both bleaching protocols took the same time and achieved similar tooth color since the $\vec{s}$ second in-office bleaching session was performed on the same day when the patients allocated to the combined protocol ended the at-home home bleaching. Therefore, the second null hypothesis of the study was also accepted.

Both protocols resulted in $\triangle \mathrm{SGU} \approx 5.0$ and $\Delta \mathrm{E} \approx 9.0$, which are consistent with the color changes observed in other clinical trials for either at-home or in-office bleaching $(2,3)$. To obtain the desired color, the stability of the bleaching effect achieved also plays an important role. Aggressive bleaching protocols causing significant pulp damage can prompt this tissue to produce reactional dentin, resulting in rebound effect on the bleached teeth (32). In the present study, tooth color was re-evaluated 6 months after the end of the bleaching protocols and no difference was observed in the color measured 1 week after the final bleaching procedures, demonstrating stability of tooth color achieved with both protocols. The outcomes of the present study reveal that the bleaching protocol combining both in-office and at-home procedures was unable to accelerate the bleaching effect when compared to two in-office sessions with a 1-week interval between them. Furthermore, there was no difference in TS between the evaluated bleaching protocols.

\section{Resumo}

Este ensaio clínico controlado e randomizado avaliou o efeito da associação de procedimentos de clareamento caseiro e de consultório na sensibilidade dental (SD) e efetividade clareadora. Quarenta pacientes receberam uma sessão de clareamento de consultório com peróxido de hidrogênio a 38\%. Em seguida, os pacientes foram aleatoriamente alocados para receberem uma segunda sessão de clareamento de consultório ou para usar uma moldeira com peróxido de carbamida a 10\% por 7 dias consecutivos. 0 pior score de SD relatada durante ou após cada procedimento clareador foi mensurado usando uma escala verbal, e o risco a SD (escore diferente de 0) foi calculado. Mudança de cor foi mensurada 7 dias após cada sessão de clareamento de consultório (para paciente submetidos a apenas procedimentos de consultório) ou após o fim do clareamento de caseiro (para o protocolo combinado) e 6 meses após o último procedimento clareador para os dois protocolos de clareamento. A cor foi mensurada através de um espectrofotômetro e pelo uso das escalas Vita Clássica e Bleach guide. As análises estatísticas foram realizadas para verificar possíveis diferenças em relação aos desfechos e para analisar o efeito do momento da mensuração nas mudanças de cor. 0 protocolo clareador não afetou o risco e o nível máximo de SD relatado, independentemente do tempo de avaliação. Na avaliação de cor, o protocolo clareador também não afetou a cor final dos dentes. Como conclusão, após uma sessão de clareamento de consultório, não há diferença na efetividade clareadora e na SD em realizar uma segunda sessão de consultório ou associá-la com uma semana de clareamento caseiro.

\section{References}

1. Moghadam FV, Majidinia S, Chasteen J, Ghavamnasiri M. The degree of color change, rebound effect and sensitivity of bleached teeth associated with at-home and power bleaching techniques: A randomized clinical trial. Eur J Dent 2013;7:405-411.

2. de Deus JL, Wambier LM, Kossatz S, Loguercio AD, Reis A. At-home vs in-office bleaching: A systematic review and meta-analysis. Oper Dent 2016;41:341-356.

3. Rezende $M$, Loguercio AD, Kossatz $S$, Reis A. Predictive factors on the efficacy and risk/intensity of tooth sensitivity of dental bleaching: A multi regression and logistic analysis. J Dent 2016;45:1-6.

4. Dahl JE, Pallesen U. Tooth bleaching - a critical review of the biological aspects. Crit Rev Oral Biol Med 2003;14:292-304.

5. Goldberg M, Grootveld M, Lynch E. Undesirable and adverse effects of tooth-whitening products: a review. Clin Oral Investig 2010;14:1-10.

6. Lazarchik DA, Haywood VB. Use of tray-applied 10 percent carbamide peroxide gels for improving oral health in patients with special-care needs. J Am Dent Assoc 2010;141:639-634.

7. Paula $A B$, Dias MI, Ferreira MM, Carrilho $T$, Marto $C M$, Casalta J, et al.. Effects on gastric mucosa induced by dental bleaching--an experimental study with $6 \%$ hydrogen peroxide in rats. J Appl Oral Sci 2015;23:497-507.

8. Kossatz S, Martins G, Loguercio AD, Reis A. Tooth sensitivity and bleaching effectiveness associated with use of a calcium-containing in-office bleaching gel. J Am Dent Assoc 2012;143:e81-e87.

9. Correa AC, Santana TR, Nahsan FP, Loguercio AD, Faria-E-Silva AL. The impact of a customized tray on in-office bleaching tooth sensitivity: a randomized clinical trial. Oper Dent 2016;41:15-22.

10. Paula EA, Nava JA, Rosso C, Benazzi CM, Fernandes KT, Kossatz S, et al.. In-office bleaching with a two- and seven-day intervals between clinical sessions: A randomized clinical trial on tooth sensitivity. J Dent 2015;43:424-429.

11. Kugel G, Perry RD, Hoang E, Scherer W. Effective tooth bleaching in 5 days: using a combined in-office and at-home bleaching system. Compend Contin Educ Dent 1997;18:378, 380-383.

12. Deliperi S, Bardwell DN, Papathanasiou A. Clinical evaluation of a combined in-office and take-home bleaching system. J Am Dent Assoc 2004;135:628-634.

13. Matis BA, Cochran MA, Wang G, Eckert GJ. A clinical evaluation of two in-office bleaching regimens with and without tray bleaching. Oper Dent 2009;34:142-149.

14. Rezende M, Ferri L, Kossatz S, Loguercio AD, Reis A. Combined bleaching technique using low and high hydrogen peroxide in-office bleaching gel. Oper Dent 2016; 41:388-396.

15. da Silva Marques DN, Silveira JM, Marques JR, Amaral JA, Guilherme $N M$, da Mata AD. Kinetic release of hydrogen peroxide from different whitening products. Eur J Esthet Dent 2012;7:344-352.

16. Paula E, Kossatz S, Fernandes D, Loguercio A, Reis A. The effect of 
perioperative ibuprofen use on tooth sensitivity caused by in-office bleaching. Oper Dent 2013;38:601-608.

17. Reis A, Tay LY, Herrera DR, Kossatz S, Loguercio AD. Clinical effects of prolonged application time of an in-office bleaching gel. Oper Dent 2011;36:590-596.

18. Markowitz K. Pretty painful: Why does tooth bleaching hurt? Med Hypotheses 2010;74:835-840.

19. de Souza Costa CA, Riehl H, Kina JF, Sacono NT, Hebling J. Human pulp responses to in-office tooth bleaching. Oral Surg Oral Med Oral Pathol Oral Radiol Endod 2010;109:e59-e64.

20. Kielbassa AM, Maier M, Gieren AK, Eliav E. Tooth sensitivity during and after vital tooth bleaching: A systematic review on an unsolved problem. Quintessence Int 2015;46:881-897

21. Mena-Serrano AP, Parreiras SO, do Nascimento EM, Borges CP, Berger $\mathrm{SB}$, Loguercio $\mathrm{AD}$, et al.. Effects of the concentration and composition of in-office bleaching gels on hydrogen peroxide penetration into the pulp chamber. Oper Dent 2015;40:E76-E82.

22. de Almeida LC, Soares DG, Gallinari MO, de Souza Costa CA, Dos Santos PH, Briso AL. Color alteration, hydrogen peroxide diffusion, and cytotoxicity caused by in-office bleaching protocols. Clin Oral Invest 2015;19:673-680.

23. Lepinski AM, Hargreaves KM, Goodis HE, Bowles WR. Bradykinin levels in dental pulp by microdialysis. J Endod 2000;26:744-747.

24. Caviedes-Bucheli J, Ariza-García G, Restrepo-Méndez S, Ríos-Osorio N, Lombana N, Muñoz HR. The effect of tooth bleaching on substance $P$ expression in human dental pulp. J Endod 2008;34:1462-1425.

25. Seale NS, McIntosh JE, Taylor AN. Pulpal reaction to bleaching of teeth in dogs. J Dent Res 1981;60:948-953.
26. Trindade FZ, Ribeiro AP, Sacono NT, Oliveira CF, Lessa FC, Hebling J, et al.. Trans-enamel and trans-dentinal cytotoxic effects of a $35 \% \mathrm{H} 2 \mathrm{O} 2$ bleaching gel on cultured odontoblast cell lines after consecutive applications. Int Endod J 2009;42:516-524.

27. Kina JF, Huck C, Riehl H, Martinez TC, Sacono NT, Ribeiro AP, et al.. Response of human pulps after professionally applied vital tooth bleaching. Int Endod J 2010;43:572-580.

28. Soares DG, Basso FG, Hebling J, de Souza Costa CA. Concentrations of and application protocols for hydrogen peroxide bleaching gels: effects on pulp cell viability and whitening efficacy. J Dent 2014;42:185-198.

29. Moncada G, Sepúlveda D, Elphick K, Contente M, Estay J, Bahamondes $V$, et al.. Effects of light activation, agent concentration, and tooth thickness on dental sensitivity after bleaching. Oper Dent 2013;38:467476.

30. Perdigão J. Dental whitening - revisiting the myths. Northwest Dent 2010;89:19-21,23-26.

31. Sa $Y$, Sun $L$, Wang $Z, M a ~ X$, Liang $S$, et al.. Effects of two in-office bleaching agents with different $\mathrm{pH}$ on the structure of human enamel: an in situ and in vitro study. Oper Dent 2013;38:100-110.

32. Costa CA, Riehl H, Kina JF, Sacono NT, Hebling J. Human pulp responses to in-office tooth bleaching. Oral Surg Oral Med Oral Pathol Oral Radiol Endod 2010;109:e59-e64.
Received May 26, 2017 Accepted December 12, 2017 